\title{
Perbandingan Minat Belajar Menggunakan Pembelajaran Model Diskusi Dengan Model Pengajaran Langsung Peserta Didik Kelas XI SMA Negeri I Batangtoru
}

\author{
Ahmad Fadlan \\ Universitas Pembangunan Panca Budi \\ ahmad_fadlan@dosen.pancabudi.ac.id
}

\begin{abstract}
Abstrak
Penelitian ini membahas tentang pembelajaran model diskusi dan pengajaran langsung. Tujuan dari penelitian ini adalah untuk mengetahui apakah terdapat perbandingan minat belajar jika pembelajaran model diskusi dan pengajaran langsung digunakan dalam proses pembelajaran. Sampel penelitian ini adalah peserta didik kelas XI IPS 1 dan XI IPS 2 yang berjumlah 75 orang di SMA Negeri 1 Batangtoru. Data yang digunakan adalah angket dan hasil tes peserta didik. Data dianalisa dengan menggunakan rumus pengujian hipotesis yaitu t-test polled varians. Dari hasil analisa data, ditemukan bahwa $t_{\text {hitung }}>t_{\text {tabel }}$ atau 12,67> 2,000. Ini artinya Ha diterima dan Ho ditolak. Hal ini juga menunjukkan bahwa terdapat (ada) perbedaan antara minat belajar peserta didik menggunakan pembelajaran model diskusi kelas dengan model pengajaran langsung terhadap peserta didik kelas XI SMA Negeri 1 Batangtoru.
\end{abstract}

Kata kunci : minat belajar, pembelajaran model diskusi, pengajaran langsung

\section{Abstract}

This research was discussed about discussion learning model and direct teaching model. The aim of this research was to know whether there was a comparison of learning interest if discussion learning model and direct teaching model were used on the learning process. The sample of this research was the students of class XI IPS 1 and XI IPS 2 were accumulated as 75 students at SMA Negeri 1 Batangtoru. The data used were questionnaire and students' test result. The data was analyzed by using hyphotesis testing formula namely t-test polled varians. From the data analysis, it was found that $t_{\text {counted }}>t_{\text {table }}$ or 12,67> 2,000. This meant that Ha was accepted and Ho was rejected. This also showed that there was a comparison of students' learning interest by using discussion learning model and direct teaching model on students at SMA Negeri 1 Batangtoru.

Keywords : learning interest, discussion learning model, direct teaching model

\section{PENDAHULUAN}

Kegiatan pembelajaran adalah suatu usaha dalam mengarahkan peserta didik untuk mencapai hasil pembelajaran yang telah ditentukan. Pembelajaran haruslah berfokus terhadap kondisi peserta didik. Peserta didik tentunya memiliki karakter dan keunikan tersendiri antara satu dengan lainnya. Oleh karena itu, guru hendaknya memberi perhatian lebih terhadap perbedaan antar peserta didik tersebut.

Menurut Arikunto (2003:4), ada beberapa karakter peserta didik yang berbeda satu dengan lainnya, seperti: (1) semangat belajar yang rendah; (2) mencari jalan untuk menjadi pintar; (3) tidak mengerti tujuan pembelajaran; serta (4) tidak aktif selama pembelajaran. Upaya guru dalam memusatkan perhatian lebih dalam pembelajaran berguna untuk merangsang minat belajar peserta didik dengan karakter yang berbeda tersebut. Minat belajar ini diperlukan untuk memunculkan kecenderungan dan keinginan belajar terhadap sesuatu. Pemusatan perhatian dalam proses pembelajaran sangat diperlukan.

Menurut Syah (2005:151), minat dianggap sebagai salah satu factor penting dalam memberikan 
pengaruh terhadap kualitas dan pencapaian hasil belajar peserta didik. Peserta didik yang memiliki minat akan proses pembelajaran tentunya akan memiliki perasaan senang untuk mempelajari pelajaran-pelajaran yang dipelajarinya di sekolah. Hal ini juga yang berpengaruh untuk menentukan derajat keaktifan siswa, jika pelajaran yang dipelajari tidak sesuai dengan minat peserta didik, peserta didik tidak akan belajar dengan antusias. Oleh karena itu, guru hendaknya berusaha untuk menciptakan kondisi belajar dimana peserta didik selalu merasa ingin dan antusias saat belajar. Banyak cara yang bias dilakukan oleh guru, salah satunya dengan menerapkan suatu model pembelajaran yang tentunya dapat meningkatkan minat peserta didik dalam proses pembelajaran.

Berdasarkan hasil wawancara yang telah dilaksanakan dengan guru bidang studi Ekonomi di SMA Negeri I Batangtoru yaitu ibu Kusmalina Simbolon, S.Pd, beliau menyatakan bahwa peserta didik kurang aktif dalam proses pembelajaran dan hanya sedikit peserta didik yang tertarik dengan pelajaran ekonomi. Penyebab hal tersebut dikarenakan minat dan rasa ingin tahu peserta didik terhadap mata pelajaran ekonomi masih sangat rendah dan anggapan pelajaran ekonomi terlalu membosankan karena terlalu banyak materi-materi yang harus pelajari dan terkadang harus dihapal sehingga peserta didik kurang aktif dalam proses pembelajaran.

Untuk memperbaiki keadaan tersebut salah satu upaya yang harus dilakukan adalah dengan menyesuaikan model pembelajaran yang efektif dan kondusif, agar peserta didik lebih mudah memahami materi pembelajaran yang disajikan guru di sekolah. Penggunaan model pembelajaran yang kurang tepat, dapat mengakibatkan peserta didik merasa jenuh saat mengikuti proses pembelajaran di kelas. Sebagian besar waktu pelajaran yang digunakan oleh guru hanya digunakan untuk menerangkan materi pelajaran sehingga tidak terjalinlah interaksi antara guru dan peserta didik kemudian dalam pelajaran ekonomi, peserta didik hanya menerima informasi satu arah dari guru tanpa mnegetahui makna informasi dan aplikasi dari ekonomi dalam kehidupan sehari-hari. Padahal dewasa ini, banyak model-model pembelajaran yang digunakan oleh guru, diantaranya adalah pembelajaran model diskusi kelas dan pengajaran langsung.

Pembelajaran model diskusi kelas adalah model pembelajaran yang bersifat interaktif dan kolaboratif sehingga mampu secara efektif memberdayakan potensi-potensi kognisi dan afeksi peserta didik menjadi pribadi yang kritis, demokratis, toleran dan dewasa menghadapi persoalan-persoalan yang dihadapi. Sedangkan model pengajaran langsung adalah suatu model pengajaran yang bersifat teacher centered.

Berdasarkan penjelasan di atas, penelitian ini dilakukan untuk mengetahui perbandingan minat belajar menggunakan pembelajaran model diskusi kelas dengan model pengajaran langsung terhadap peserta didik kelas XI SMA Negeri 1 Batangtoru.

\section{TINJAUAN PUSTAKA}

Menurut Kartono (2005), minat belajar dapat diartikan sebagai waktu tertentu dari kecenderungan jiwa yang diarahkan secara intensif kepada suatu objek (perasaan, emosional) yang didalamnya terdapat elemen-elemen efektif (emosi) yang kuat. Menurut Hardjana (2005), minat belajar adalah kecenderungan hati peserta didik yang tinggi terhadap pembelajaran yang muncul karena kebutuhan, yang dirasakan atau keinginan akan hal tertentu.

Bisa dikatakan bahwa minat adalah kecenderungan yang terus dilakukan dengan perasaan yang senang dan memberikan dampak yang baik terhadap hasil kegiatan yang dilakukan. Minat merupakan keinginan yang datang dari hati nurani untuk ikut serta dalam proses pembelajaran. Semakin besar minatnya, maka semakin besar pula semangat dan hasil kerjanya. Keinginan seseorang yang tinggi untuk belajar sangat berdampak terhadap hasil pembelajaran yang diperoleh oleh peserta didik itu sendiri. Tanpa adanya minat atau keinginan yang besar dalam belajar, mustahil seorang individu akan mendapatkan hasil belajar yang baik. 
Menurut Daryanto (2014), model pembelajaran adalah suatu perencanaan atau rancangan yang digunakan oleh guru sebagai pedoman dalam merencanakan pembelajaran di kelas atau pembelajaran dalam tutorial.

Pembelajaran model diskusi misalnya mempunyai arti suatu kondisi dimana guru dan para peserta didik, atau antara peserta didik dengan peserta didik yang lain berbincang satu sama lain, dan membahasa berbagai gagasan dan pendapat mereka. Pembelajaran model diskusi adalah cara penyajian pembelajaran, di mana peserta didik diberikan suatu masalah yang bisa saja berupa pernyataan atau pertanyaan yang bersifat problematis untuk dibahas dan dipecahkan bersama-sama (Djamarah dan Zain, 2006).

Bisa dikatakan bahwa dalam pembelajaran model diskusi, akan ada tujuan yang juga bisa dicapai oleh peserta didik. Adapun tiga tujuan pembelajaran yang penting, yaitu pertama, meningkatkan cara berpikir peserta didik dengan cara membantu mereka berpikir aktif dalam memahami pelajaran. Kedua, menumbuhkan keaktifan dan partisipasi peserta didik. Ketiga, membantu peserta didik mempelajari kemampuan komunikasi dan proses berpikir.

Sedangkan model pengajaran langsung sering disebut juga dengan model pengajaran aktif (active teaching model). Pengajaran langsung merujuk kepada suatu model pengajaran yang bersifat teacher centered. Model pengajaran langsung berlandaskan kepada teori belajar behaviorisme yang menyatakan bahwa manusia belajar dan bertindak dengan cara spesifik sebagai hasil dari tindakan penguatan melalui pengamatan di dalam memori jangka pendeknya tentang perilaku orang lain (Nur, 2008).

Fathurrohman (2015) berpendapat bahwa pada pengajaran langsung, guru memulai pembelajaran dengan menjelaskan tujuan, latar belakang pembelajaran, dan mempersiapkan siswa untuk menerima pelajaran, kemudian melakukan demonstrasi pengetahuan dan keterampilan tertentu. Pelajaran yang diberikan termasuk juga pemberian kesempatan kepada siswa untuk melakukan pelatihan dan pemberian umpan balik terhadap hasil pemahaman siswa.

\section{METODE PENELITIAN}

Jenis penelitian yang digunakan adalah penelitian komparatif. Menurut Sugiyono (2013), pendekatan studi komparatif merupakan penelitian yang melakukan perbandingan terhadap satu variabel atau lebih pada dua atau lebih sampel yang berbeda, atau pada waktu yang berbeda pula.

Populasi dalam penelitian ini adalah seluruh peserta didik kelas XI IPS SMA Negeri 1 Batangtoru yang terdiri dari 3 (tiga) kelas. Sedangkan sampel dalam penelitian ini diambil dengan menggunakan teknik Cluster Random Sampling dengan cara mengambil 2 (dua) kelas secara acak dari 3 kelas yang ada dan terpilihlah 2 kelas sebagai sampel yaitu kelas XI IPS 1 sebagai kelas eksperimen dan XI IPS 2 sebagai kelas kontrol. Sehingga yang menjadi sampel dalam penelitian ini adalah peserta didik kelas X IPS 1 dan X IPS 2 yang berjumlah 75 peserta didik.

Data dikumpulkan dengan cara membagikan angket dan tes berupa pertanyaan kepada peserta didik dengan bentuk multiple choice dimana angket untuk variabel $\mathrm{X}_{1}$ dan variabel $\mathrm{X}_{2}$, berjumlah 15 butir soal dan untuk variabel Y berjumlah 10 soal tes.

Adapun rumus yang dipergunakan untuk menguji hipotesis dimaksud adalah rumus " $t$-test polled varians", yaitu: 


$$
t=\frac{\bar{X}_{1}-\bar{X}_{2}}{\sqrt{\frac{\left(n_{1}-1\right) S_{1}^{2}+\left(n_{2}-1\right) S_{2}^{2}}{n_{1}+n_{2}-2}\left(\frac{1}{n_{1}}+\frac{1}{n_{2}}\right)}}
$$

Keterangan:

$t=$ Nilai $\mathrm{t}$ yang dihitung

$\overline{X 1}=$ Mean dan rata-rata kelas

$\overline{X_{2}}=$ Mean dan rata-rata kelas

$S_{1}=$ Standar deviasi nilai rata-rata peserta didik

$S_{2}=$ Standar deviasi nilai rata-rata peserta didik

$N_{1}=$ Jumlah peserta didik yang menjadi sampel

N2 = Jumlah peserta didik yang menjadi sampel

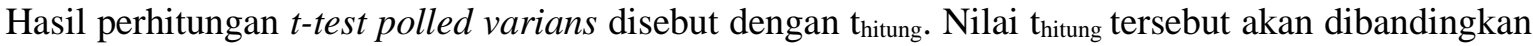
dengan nilai $t_{\text {tabel }}$ untuk melihat apakah ada perbandingan minat belajar peserta didik menggunakan pembelajaran model diskusi kelas dengan model pengajaran langsung. Apabila $t_{\text {hitung }}$ lebih besar dari pada $t_{\text {tabel, }}$ maka Ha diterima dan Ho ditolak, sebaliknya apabila $t_{\text {hitung }}$ lebih kecil dari pada $t_{\text {tabel }}$, maka Ha ditolak dan Ho diterima.

\section{HASIL DAN PEMBAHASAN}

Tabel 1.

Nilai $t$-test antara variabel $\mathrm{X}_{1}$ dan variabel $\mathrm{X}_{2}$

\begin{tabular}{|c|c|c|c|c|c|c|}
\hline No & $\mathrm{X}_{1}$ & $\mathrm{X}_{2}$ & $\mathrm{X}_{1}-\overline{\mathrm{X}_{1}}$ & $\mathrm{X}_{2}-\overline{\mathrm{X}_{2}}$ & $\left(\mathrm{X}_{1}-\overline{\mathrm{X}_{1}}\right)^{2}$ & $\left(\mathrm{X}_{2}-\overline{\mathrm{X}_{2}}\right)^{2}$ \\
\hline 1 & 61,5 & 53 & 0,26 & $-2,54$ & 0,0676 & 6,4516 \\
\hline 2 & 56 & 49 & $-5,24$ & $-6,54$ & 27,4576 & 42,7716 \\
\hline 3 & 66 & 61,5 & 4,76 & 5,96 & 22,6576 & 35,5216 \\
\hline 4 & 61 & 60,5 & $-0,24$ & 4,96 & 0,0576 & 24,6016 \\
\hline 5 & 60 & 56,5 & $-1,24$ & 0,96 & 1,5376 & 0,9216 \\
\hline 6 & 62 & 54,5 & 0,76 & $-1,04$ & 0,5776 & 1,0816 \\
\hline 7 & 60,5 & 53,5 & $-0,74$ & $-2,04$ & 0,5476 & 4,1616 \\
\hline 8 & 56,5 & 50,5 & $-4,74$ & $-5,04$ & 22,4676 & 25,4016 \\
\hline 9 & 63,5 & 50 & 2,26 & $-5,54$ & 5,1076 & 30,6916 \\
\hline 10 & 61 & 53 & $-0,24$ & $-2,54$ & 0,0576 & 6,4516 \\
\hline 11 & 60 & 62,5 & $-1,24$ & 6,96 & 1,5376 & 48,4416 \\
\hline 12 & 61,5 & 54 & 0,26 & $-1,54$ & 0,0676 & 2,3716 \\
\hline 13 & 55,5 & 64 & $-5,74$ & 8,46 & 32,9476 & 71,5716 \\
\hline 14 & 58 & 48,5 & $-3,24$ & $-7,04$ & 10,4976 & 49,5616 \\
\hline 15 & 67 & 53,5 & 5,76 & $-2,04$ & 33,1776 & 4,1616 \\
\hline 16 & 59 & 59 & $-2,24$ & 3,46 & 5,0176 & 11,9716 \\
\hline 17 & 60 & 57,5 & $-1,24$ & 1,96 & 1,5376 & 3,8416 \\
\hline 18 & 61 & 58,5 & $-0,24$ & 2,96 & 0,0576 & 8,7616 \\
\hline 19 & 65,5 & 50,5 & 4,26 & $-5,04$ & 18,1476 & 25,4016 \\
\hline 20 & 67 & 55 & 5,76 & $-0,54$ & 33,1776 & 0,2916 \\
\hline
\end{tabular}




\begin{tabular}{|c|c|c|c|c|c|c|}
\hline No & $\mathrm{X}_{1}$ & $\mathrm{X}_{2}$ & $\mathrm{X}_{1}-\overline{X_{1}}$ & $\mathrm{X}_{2}-\overline{\mathrm{X}_{2}}$ & $\left(\mathrm{X}_{1}-\overline{\bar{X}_{1}}\right)^{2}$ & $\left(\mathrm{X}_{2}-\overline{\mathrm{X}_{2}}\right)^{2}$ \\
\hline 21 & 61,5 & 52,5 & 0,26 & $-3,04$ & 0,0676 & 9,2416 \\
\hline 22 & 61 & 60 & $-0,24$ & 4,46 & 0,0576 & 19,8916 \\
\hline 23 & 61 & 53 & $-0,24$ & $-2,54$ & 0,0576 & 6,4516 \\
\hline 24 & 63,5 & 47 & 2,26 & $-8,54$ & 5,1076 & 72,9316 \\
\hline 25 & 57 & 55,5 & $-4,24$ & $-0,04$ & 17,9776 & 0,0016 \\
\hline 26 & 65 & 62 & 3,76 & 6,46 & 14,1376 & 41,7316 \\
\hline 27 & 60 & 53 & $-1,24$ & $-2,54$ & 1,5376 & 6,4516 \\
\hline 28 & 61 & 58 & $-0,24$ & 2,46 & 0,0576 & 6,0516 \\
\hline 29 & 60 & 60,5 & $-1,24$ & 4,96 & 1,5376 & 24,6016 \\
\hline 30 & 61 & 51 & $-0,24$ & $-4,54$ & 0,0576 & 20,6116 \\
\hline 31 & 54 & 59,5 & $-7,24$ & 3,96 & 52,4176 & 15,6816 \\
\hline 32 & 61 & 50,5 & $-0,24$ & $-5,04$ & 0,0576 & 25,4016 \\
\hline 33 & 65 & 61,5 & 3,76 & 5,96 & 14,1376 & 35,5216 \\
\hline 34 & 66,5 & 61 & 5,26 & 5,46 & 27,6676 & 29,8116 \\
\hline 35 & 61,5 & 54 & 0,26 & $-1,54$ & 0,0676 & 2,3716 \\
\hline 36 & 61,5 & - & 0,26 & - & 0,0676 & - \\
\hline 37 & 65,5 & - & 4,26 & - & 18,1476 & - \\
\hline 38 & 61 & - & $-0,24$ & - & 0,0576 & - \\
\hline 39 & 59 & - & $-2,24$ & - & 5,0176 & - \\
\hline 40 & 61 & - & $-0,24$ & - & 0,0576 & - \\
\hline Jumlah & 2449,5 & 1987,5 & & & 374,994 & 721,186 \\
\hline & & & & & & \\
\hline
\end{tabular}

Tabel di atas menunjukkan hasil perhitungan dari hasil angket (variabel $\mathrm{X}_{1 \text { ) }}$ dan hasil tes peserta didik (variabel $\mathrm{X}_{2}$ ). Kemudian, dengan menggunakan data dalam tabel di atas, maka dilakukan pengujian hipotesa, peneliti menggunakan rumus " $t$-test polled varians" yaitu:

$$
t=\frac{\bar{X}_{1}-\bar{X}_{2}}{\sqrt{\frac{\left(n_{1}-1\right) S_{1}^{2}+\left(n_{2}-1\right) S_{2}^{2}}{n_{1}+n_{2}-2}\left(\frac{1}{n_{1}}+\frac{1}{n_{2}}\right)}}
$$

Dengan $\mathrm{SD}=\sqrt{\frac{\sum F_{1}\left(x_{1}-\overline{\mathrm{X}_{2}}\right)^{2}}{(n-1)}}$

Dari data yang diperoleh ialah:

$$
\begin{aligned}
\mathrm{N}_{1} & =40 \\
\mathrm{~N}_{2} & =35 \\
\overline{X_{1}} & =61,24 \\
\overline{\mathrm{X}_{2}} & =55,54 \\
\mathrm{SD}\left(S_{1}^{2}\right) & =3,10
\end{aligned}
$$$$
\mathrm{SD}\left(S_{2}^{2}\right)=4,60
$$

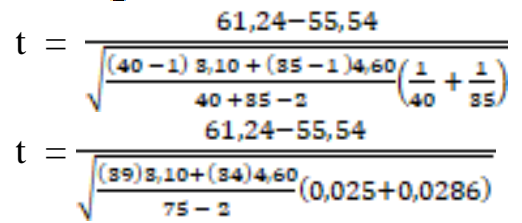


$\mathrm{t}=\frac{5,7}{\sqrt{\frac{120,99+156,4}{7 \mathrm{~g}}(0,0536)}}$

$\mathrm{t}=\frac{5,7}{\sqrt{\frac{2778}{78}(0,0536)}}$

$\mathrm{t}=\frac{5,7}{\sqrt{3,8(0,0536)}}$

$\mathrm{t}=\frac{5,7}{\sqrt{0,20368}}$

$\mathrm{t}=\frac{5,7}{0,45}$

$\mathrm{t}=12,67$

Dari hasil perhitungan $t$-test polled varians tersebut, maka didapatkan hasil $t_{\text {hitung }}$ sebesar 12,67 dengan melihat daftar $t_{\text {tabel }}$ dengan jumlah sampel 75 kemudian digunakan derajat kebebasan $(\mathrm{dk})=\mathrm{n}_{1}$ $+\mathrm{n}_{2}-2$ dan taraf kesalahan 5\% adalah 2,000, sesuai dengan ketentuan jika $\mathrm{t}_{\text {hitung }}$ lebih besar (>) dari $\mathrm{t}_{\text {tabel }}$ dengan kata lain $(12,67>2,000)$ maka hipotesis alternatif Ha dapat diterima.

Berdasarkan hasil yang diperoleh menunjukkan $t_{\text {hitung }}>t_{\text {tabel }}$ atau 12,67> 2,000 dan ini artinya Ha diterima dan Ho ditolak. Hal ini berarti bahwa terdapat (ada) perbedaan antara minat belajar peserta didik menggunakan pembelajaran model diskusi kelas dengan model pengajaran langsung dalam bidang studi ekonomi materi pokok perdagangan internasional peserta didik kelas XI SMA Negeri 1 Batangtoru.

\section{KESIMPULAN}

Berdasarkan hasil pengolahan dan penganalisaan data yang dilakukan sebelumnya, dapat disimpulkan bahwa pembelajaran model diskusi kelas dan model pengajaran langsung memiliki pengaruh signifikan terhadap minat belajar peserta didik dan ada perbandingan di antara keduanya.

Hal tersebut dapat dilihat dari hasil pengujian hipotesis sebelumnya dimana dikatakan bahwa hipotesis alternatif (Ha) diterima. Kesimpulan akhirnya adalah ada perbandingan antara kedua variable tersebut.

\section{DAFTAR PUSTAKA}

Arikunto, S. (2003). Prosedur penelitian suatu praktek. Jakarta: Bina Aksara, 3.

Mohammad, A. (2008). Penelitian tindakan kelas. Bandung: CV. Wacana Prima.

Daryanto \& Rahardjo, M. (2014). Model pembelajaran inovatif. Yogyakarta: Gava Media.

Dimyanti \& Mudjiono. (2003). Makna dan konsep pembelajaran. Bandung: Alfabeta.

Djamarah, S. B., \& Zain, A. (2006). Strategi belajar mengajar. Jakarta: Rineka Cipta, 46.

Fathurrohman, M. (2015). Model-Model Pembelajaran Inovatif (Pertama; N. Hidayah, ed.). Jogjakarta: Ar-Ruzz Media.

Hardjana. (2005). Psikologi pendidikan. Jakarta: Aksara Baru.

Kartono. (2005). Bimbingan belajar di perguruan tinggi. Jakarta: Raja Grafindo Persada. 


\section{LI}

Jurnal Humaniora Teknologi

p-ISSN: 2443-1842

Volume 6, Nomor 1, Mei 2020

e-ISSN: $2614-3682$

Sugiyono. (2013). Metode penelitian pendidikan (Pendekatan Kuantitatif, Kualitatif, dan R\&D). Bandung: Alfabeta.

Syah, M. (2004). Psikologi pendidikan dengan pendekatan terbaru. Bandung: Remaja Rosdakarya. 


\section{Lampiran 1}

\section{Angket \\ Pembelajaran Model Diskusi Kelas}

Nama

Kelas

1. Apakah anda sering melakukan diskusi kelas ?
a. Ya
b. Kadang-kadang
c. Tidak

2. Apakah anda senang dengan model pembelajaran diskusi kelas?
a. Ya
b. Kadang-kadang
c. Tidak

3. Apakah anda merasa cocok dengan pembelajaran model diskusi kelas ?
a. Ya
b. Kadang-kadang
c. Tidak

4. Apakah anda merasa jenuh apabila guru anda hanya menerangkan materi tanpa memperhatikan peserta didiknya ?
a. Ya
b. Kadang-kadang
c. Tidak

5. Apakah anda aktif belajar dengan adanya pembelajaran model diskusi kelas ?
a. Ya
b. Kadang-kadang
c. Tidak

6. Apakah anda dapat menjawab pertanyaan yang diberikan oleh guru tentang materi perdagangan internasional dengan menggunakan pembelajaran model diskusi kelas ?
a. Ya
b. Kadang-kadang
c. Tidak

7. Dalam diskusi kelas, apakah anda selalu memberikan pendapat?
a. Ya
b. Kadang-kadang
c. Tidak

8. Apakah anda menghargai pendapat teman anda dalam diskusi kelas ketika teman anda memberikan jawaban yang salah ?
a. Ya
b. Kadang-kadang
c. Tidak

9. Apakah guru anda menjelaskan tujuan dalam mengerjakan tugas yang diberikan pada setiap diskusi kelas ?
a. Ya
b. Kadang-kadang
c. Tidak

10. Apakah menurut anda model ceramah kurang sesuai untuk penyampaian materi karena membosankan dan monoton kepada guru ?
a. Ya
b. Kadang-kadang
c. Tidak

11. Apakah anda merasa belajar tidak lagi membosankan dengan menggunakan model pembelajaran diskusi kelas?
a. Ya
b. Kadang-kadang
c. Tidak

12. Apakah minat belajar anda semakin meningkat ketika model pembelajaran diskusi kelas diterapkan saat proses pembelajaran berlangsung ?
a. Ya
b. Kadang-kadang
c. Tidak

13. Apakah dengan model diskusi kelas anda semakin mudah memahami materi pelajaran ?
a. Ya
b. Kadang-kadang
c. Tidak

14. Apakah anda puas dengan penilaian yang diberikan oleh guru dalam pembelajaran model diskusi kelas?
a. Ya
b. Kadang-kadang
c. Tidak

15. Apakah anda mendapat pengalaman belajar dalam pembelajaran model diskusi kelas?
a. Ya
b. Kadang-kadang
c. Tidak 


\section{Lampiran 2}

\section{Angket \\ Model Pengajaran Langsung}

Nama

Kelas

1. Apakah anda suka dengan pelajaran ekonomi ?
b. Ya
b. Kadang-kadang
c. Tidak

2. Apakah guru anda sering menerapkan model pengajan langsung saat proses belajar mengajar berlangsung?
b. Ya
b. Kadang-kadang
c. Tidak

3. Apakah anda senang belajar dengan menggunakan model pengajaran langsung ?
b. Ya
b. Kadang-kadang
c. Tidak

4. Apakah anda selalu mentaati perintah guru saat proses belajar mengajar berlangsung ?
b. Ya
b. Kadang-kadang
c. Tidak

5. Apakah guru anda menjelaskan tujuan dari model pengajaran langsung?
b. Ya
b. Kadang-kadang
c. Tidak

6. Apabila guru anda bertanya, apakah anda akan berusaha menjawab pertanyaan tersebut ?
b. Ya
b. Kadang-kadang
c. Tidak

7. Apakah guru ekonomi anda dalam memberikan materi ekonomi selalu mencatat?
b. Ya
b. Kadang-kadang
c. Tidak

8. Apakah situasi kelas terkendali saat pembelajaran menggunakan model pengajaran langsung ?
b. Ya
b. Kadang-kadang
c. Tidak

9. Apakah anda selalu mengerti apa yang diajarkan guru dengan model pengajaran langsung ?
b. Ya
b. Kadang-kadang
c. Tidak

10. Dalam model pengajaran langsung, apakah dapat mendorong minat anda untuk mengulang pelajaran yang telah dijelaskan oleh guru ?
b. Ya
b. Kadang-kadang
c. Tidak

11. Apakah dengan menggunakan model pengajaran langsung dapat menciptakan interaksi antara guru dan anda?
b. Ya
b. Kadang-kadang
c. Tidak

12. Apakah anda dapat menjawab soal-soal ekonomi tentang perdagangan internasional dengan baik dan benar melalui model pengajaran internasional ?
b. Ya
b. Kadang-kadang
c. Tidak

13. Apakah anda dapat mengerti materi perdagangan internasional yang dijelaskan guru dengan menggunakan model pengajaran langsung ?
b. Ya
b. Kadang-kadang
c. Tidak

14. Apakah dengan model pengajaran langsung anda semakin mudah untuk menguasai materi pelajaran ekonomi?
b. Ya
b. Kadang-kadang
c. Tidak

15. Apakah anda merasa puas dengan penilaian yang telah diberikan oleh guru setelah model pengajaran langsung diterapkan ?
b. Ya
b. Kadang-kadang
c. Tidak 